\title{
An evaluation of treatment with heparin in the haemolytic-uraemic syndrome successfully treated by peritoneal dialysis
}

\author{
M G COULTHARD
}

Department of Paediatrics, Royal Victoria Infirmary, Newcastle upon Tyne

SUMMARY Nine children had 10 attacks of the haemolytic-uraemic syndrome in an 11-month period. One child had 2 slight episodes. The remaining 8 children each had a severe attack which required peritoneal dialysis and, of these, the first 4 were also treated with heparin. All the patients survived without sequelae and the rate of recovery of dialysed patients was unaffected by the use of heparin. Peritoneal dialysis alone is therefore recommended as a simple and effective form of treatment for the haemolytic-uraemic syndrome. No infective aetiological agent could be identified and the distribution of HLA antigens among the children was unremarkable.

The haemolytic-uraemic syndrome (HUS) was first described 24 years ago. ${ }^{1}$ It is characterised by acute renal failure, thrombocytopenia, and a haemolytic anaemia with schizocytes present in the blood film. It is rare in Britain but if it does occur it tends to do so as a small outbreak in young children, generally preceded either by a diarrhoeal illness or a slight infection of the upper respiratory tract.

The reported mortality of HUS has been as high as $67 \%$ but more recently $95 \%$ of patients have been reported to survive. ${ }^{3-4}$ Treatment is generally directed to the management of anaemia and renal failure, and to treatment specifically aimed at halting the intrarenal intravascular coagulation believed to occur ${ }^{5}$ in the syndrome. This has included the use of corticosteroids, ${ }^{2}$ heparin, ${ }^{6-8}$ dipyridamole and aspirin, ${ }^{8-9}$ and streptokinase. ${ }^{10}$ Because of its sporadic nature there has been little attempt at evaluating these agents in HUS, but in the few trials that have been undertaken ${ }^{7}$ no advantage could be shown over supportive treatment alone. This paper reports the results of treatment with and without heparin in two groups of 4 children all of whom received dialysis for HUS. Although not designed as a controlled trial the two groups were comparable.

\section{Patients}

All the children were treated at the Royal Victoria

Child Health Unit, Princess Mary Maternity Hospital, Newcastle upon Tyne

M G COULTHARD, honorary senior registrar
Infirmary between May 1977 and April 1978 having been referred from hospitals within a 32-mile radius.

Clinical details are given in Table 1. Case 1 had two attacks of HUS, each was slight and was treated by careful management of fluid and electrolyte balance, and blood transfusion only. She had a clinical presentation different from the other children, with a 3-day history of lethargy, anorexia, and fever followed by 12 hours of haematuria on each occasion. Between attacks she had been well.

Each of the other 8 patients had a history of diarrhoea (sometimes bloody) and vomiting, followed a few days later by oliguria or anuria. In each case as the gastrointestinal symptoms began to improve there was a fairly rapid onset of pallor and sometimes the appearance of petechiae. On admission the children were all strikingly pale and had obvious bruising around venepuncture sites. Two patients were hypertensive, one becoming severely so with a maximum blood pressure of $270 / 210 \mathrm{mmHg}$ and the presence of slight papilloedema. Case 3 was admitted to the referring hospital with a typical history but by the time he was transferred to this hospital he was in heart failure and had had prolonged fits secondary to water overload and dilutional hyponatraemia.

Eight children had the severe form of the disease ${ }^{4}$ and required dialysis. To comply with departmental policy for severely affected children the first four patients (Cases 2 to 5) were also heparinised. Case 6 however was transferred for dialysis at a time when her platelet count had already begun to rise and 
Table 1 Clinical details on admission

\begin{tabular}{|c|c|c|c|c|c|c|}
\hline Case & $\begin{array}{l}\text { Age } \\
\text { (years) }\end{array}$ & $\operatorname{Sex}$ & $\begin{array}{l}\text { Duration of } \\
\text { oliguria or } \\
\text { anuria (days) }\end{array}$ & $\begin{array}{l}\text { Presence of } \\
\text { hypertension }\end{array}$ & Fits & Presenting symptoms \\
\hline \multicolumn{7}{|c|}{ No dialysis } \\
\hline$* 1$ & $\begin{array}{l}3 \cdot 3 / 12 \\
4 \cdot 2 / 12\end{array}$ & $\mathbf{F}$ & $\begin{array}{l}\mathbf{0} \\
\mathbf{0}\end{array}$ & - & - & $\begin{array}{l}\text { Lethargy, anorexia, fever ( } 3 \text { days), and haematuria } \\
\text { (12 hours) each time }\end{array}$ \\
\hline \multicolumn{7}{|c|}{ Dialysis and heparin } \\
\hline 2 & $1 \cdot 8 / 12$ & $\mathbf{F}$ & 2 & $270 / 240$ & - & \multirow{10}{*}{$\begin{array}{l}\text { Diarrhoea (sometimes bloody) and vomiting ( } 5 \text { to } \\
10 \text { days)-beginning to improve when sudden } \\
\text { onset of pallor with bruising tendency }\end{array}$} \\
\hline 3 & $2 \cdot 10 / 12$ & $\mathbf{M}$ & 7 & - & + & \\
\hline 4 & $4 \cdot 1 / 12$ & $\mathbf{M}$ & 2 & - & - & \\
\hline 5 & $2 \cdot 11 / 12$ & $\mathbf{F}$ & $1 \cdot 5$ & - & - & \\
\hline Mean & $2 \cdot 11 / 12$ & & $3 \cdot 1$ & & & \\
\hline \multicolumn{6}{|c|}{ Dialysis alone } & \\
\hline 6 & $5 \cdot 3 / 12$ & $\mathbf{F}$ & 3 & - & - & \\
\hline 7 & $4 \cdot 6 / 12$ & $\mathbf{F}$ & 2 & - & - & \\
\hline 8 & $1 \cdot 11 / 12$ & $\mathbf{F}$ & 4 & $170 / 100$ & - & \\
\hline $\begin{array}{l}9 \\
\text { Mean }\end{array}$ & $\begin{array}{l}2 \cdot 3 / 12 \\
3 \cdot 6 / 12\end{array}$ & $\mathbf{F}$ & $3 \cdot 25$ & - & - & \\
\hline
\end{tabular}

*Case 1 had two episodes of HUS.

therefore heparin was withheld, her platelet counts continuing to show a sustained improvement. On the basis of this and her otherwise uneventful recovery, heparin was withheld from subsequent severely affected children and thus two treatment groups were fortuitously created. The patients' age ranges and the duration of diminished urinary output before dialysis were similar in the two groups, and each group had one hypertensive child.

Laboratory data were very similar in the two treatment groups (Tables 2 and 3). All the patients had typical blood films with schizocytes, fragmented cells, and pronounced thrombocytopenia. The lowest haemoglobin levels and platelet counts in both groups were similar. All the children had slightly raised plasma fibrin degradation products and normal fibrinogen levels, and all had normal clotting times except for slightly prolonged thrombin times. Complement levels were normal in all patients.

Table 2 Haematological data

\begin{tabular}{|c|c|c|c|c|c|}
\hline Case & $\begin{array}{l}\text { Lowest } H b \\
(g / d l)\end{array}$ & $\begin{array}{l}\text { Lowest } \\
\text { platelets } \\
\left(\times 10^{9} / 1\right)\end{array}$ & $\begin{array}{l}F D P \\
(\mu g / m l)\end{array}$ & $\begin{array}{l}\text { Fibrinogen } \\
(\mathrm{mg} / 100 \mathrm{ml})\end{array}$ & $\begin{array}{l}\text { Thrombin time } \\
\text { (control } 13 \mathrm{~s} \text { ) }\end{array}$ \\
\hline \multicolumn{6}{|c|}{ No dialysis } \\
\hline 1 & $\begin{array}{l}5 \cdot 6 \\
6 \cdot 4\end{array}$ & $\begin{array}{l}25 \\
35\end{array}$ & $\begin{array}{l}40 \\
30\end{array}$ & $\begin{array}{l}350 \\
200\end{array}$ & $\begin{array}{l}17 \\
20\end{array}$ \\
\hline \multicolumn{6}{|c|}{ Dialysis and heparin } \\
\hline 2 & $3 \cdot 3$ & 20 & 80 & 180 & 21 \\
\hline 3 & $6 \cdot 6$ & 18 & 40 & 150 & 14 \\
\hline 4 & $5 \cdot 3$ & 15 & 40 & 300 & 19 \\
\hline 5 & $7 \cdot 4$ & 40 & 20 & 一 & - \\
\hline Mean & $5 \cdot 5$ & 23 & 45 & 210 & 18 \\
\hline \multicolumn{6}{|c|}{ Dialysis alone } \\
\hline 6 & $6 \cdot 8$ & 60 & 60 & 200 & 21 \\
\hline 7 & $5 \cdot 7$ & 40 & 40 & 300 & 13 \\
\hline 8 & $7 \cdot 1$ & 40 & 40 & 350 & 16 \\
\hline 9 & $4 \cdot 7$ & 55 & 55 & 200 & 17 \\
\hline Mean & $6 \cdot 1$ & 49 & 49 & 262 & 17 \\
\hline
\end{tabular}

$\overline{\text { FDB }}=$ fibrin degradation products.
Table 3 Biochemical data

\begin{tabular}{|c|c|c|c|c|}
\hline \multirow[t]{2}{*}{ Case } & \multirow[t]{2}{*}{ Urea } & \multicolumn{3}{|c|}{ Predialysis values (mmol/l) } \\
\hline & & Sodium & Potassium & Bicarbonate \\
\hline \multicolumn{5}{|c|}{ No dialysis } \\
\hline $1^{*}$ & $\begin{array}{l}24 \\
41\end{array}$ & $\begin{array}{l}138 \\
131\end{array}$ & $\begin{array}{l}5 \\
4 \cdot 9\end{array}$ & $\begin{array}{l}20 \\
16\end{array}$ \\
\hline \multicolumn{5}{|c|}{ Dialysis and heparin } \\
\hline $\begin{array}{l}2 \\
3 \\
4 \\
5 \\
\text { Mean }\end{array}$ & $\begin{array}{l}84 \\
42 \\
50 \\
50 \\
56 \cdot 5\end{array}$ & $\begin{array}{l}135 \\
114 \dagger \\
127 \\
120 \\
124\end{array}$ & $\begin{array}{l}6 \cdot 9 \\
2 \cdot 7 \dagger \\
6 \cdot 6 \\
4 \cdot 3 \\
5 \cdot 1\end{array}$ & $\begin{array}{l}13 \\
11 \\
14 \\
14 \\
13\end{array}$ \\
\hline \multicolumn{5}{|c|}{ Dialysis alone } \\
\hline $\begin{array}{l}6 \\
7 \\
8 \\
9 \\
\text { Mean }\end{array}$ & $\begin{array}{l}56 \\
44 \\
50 \\
72 \\
55 \cdot 5\end{array}$ & $\begin{array}{l}139 \\
121 \\
127 \\
131 \\
130\end{array}$ & $\begin{array}{l}5 \cdot 3 \\
5 \cdot 4 \\
4 \cdot 9 \\
7 \cdot 3 \\
5 \cdot 6\end{array}$ & $\begin{array}{l}12 \\
10 \\
10 \\
14 \\
11 \cdot 5\end{array}$ \\
\hline
\end{tabular}

*Case 1 not dialysed-biochemical data taken at time of highest urea. tCase 3 fluid overloaded on admission.

The predialysis urea and bicarbonate levels were similar in the two groups. Case 3 had severe dilutional hyponatraemia and hypokalaemia from fluid overload. The other dialysed patients also showed a tendency to develop hyponatraemia, and had either abnormally high or rapidly rising potassium values.

Nose and throat swabs, blood, urine, and stool specimens were all cultured bacteriologically. Viral cultures were also obtained, as were nasopharyngeal secretions for fluorescent viral antibody staining, and in addition stools were examined under the electron microscope for rotavirus. Acute and convalescent sera were obtained for viral antibody studies.

\section{Treatment}

Patients were transfused with packed cells and 2 children also received platelets because of small 
haematemeses. Case 1 was not transfused in her second illness but was discharged with a stable haemoglobin of $7.6 \mathrm{~g} / \mathrm{dl}$ and a high $(8.4 \%)$ reticulocyte count. Her fluid and electrolyte intakes were carefully controlled to balance losses, but the other children had a more relaxed regimen once dialysis had been established.

Peritoneal dialysis was started if a high or rapidly rising plasma potassium level was present (7 patients) or if there was gross fluid overload with dilutional hyponatraemia associated with heart failure and convulsions (one patient, Case 3). Dialysis was given with hourly cycles of $25-50 \mathrm{ml} / \mathrm{kg}$ initially; thereafter it was given more frequently (usually 3 or 4 an hour) according to electrolyte response. Potassium was added to the dialysis fluid as necessary. Case 3 was dialysed initially with hyperosmolar fluid containing $63.6 \mathrm{~g} / 1$ glucose. Effluent dialysate was studied under a microscope twice daily and cultured once daily. If white cells appeared $8 \mathrm{mg}$ gentamicin was added to each litre of the dialysis fluid while awaiting the results of the bacteriological culture. The 2 hypertensive children were treated with combinations of diazoxide, hydrallazine, methyldopa, and propranolol, and the fall in blood pressure was not related to pronounced changes in body weight or fluid loss.

Table 4 Rate of recovery

\begin{tabular}{|c|c|c|c|}
\hline Case & $\begin{array}{l}\text { Time for platelets to } \\
\text { reach } \geqslant 150 \times 10^{9} / l \\
\text { (days) }\end{array}$ & $\begin{array}{l}\text { Duration of } \\
\text { dialysis } \\
\text { (days) }\end{array}$ & $\begin{array}{l}\text { Blood transfused } \\
(\mathrm{g} / \mathrm{dl})(\text { total rise in } \\
\mathrm{Hb})\end{array}$ \\
\hline \multicolumn{4}{|c|}{ No dialysis } \\
\hline 1 & $\begin{array}{l}4 \\
5\end{array}$ & $\overline{-}$ & $\stackrel{4.3}{-}^{4.3}$ \\
\hline \multicolumn{4}{|c|}{ Dialysis and heparin } \\
\hline 2 & 7 & 6 & $11 \cdot 9$ \\
\hline 3 & 9 & 14 & $10 \cdot 8$ \\
\hline 4 & 6 & 6 & $8 \cdot 5$ \\
\hline & 5 & 7 & 9.3 \\
\hline & $6 \cdot 75$ & $8 \cdot 20$ & $10 \cdot 1$ \\
\hline \multicolumn{4}{|c|}{ Dialysis alone } \\
\hline 6 & 5 & 9 & $6 \cdot 7$ \\
\hline & 8 & 6 & 9.7 \\
\hline 8 & 8 & 5 & 6.9 \\
\hline & 10 & 13 & $15 \cdot 1$ \\
\hline Mean & 7.75 & $8 \cdot 25$ & $9 \cdot 6$ \\
\hline
\end{tabular}

Heparin was administered by continuous intravenous infusion at a rate of $15-25$ units $/ \mathbf{k g}$ per hour in an attempt to maintain thrombin times at twice normal.

\section{Results and discussion}

At follow-up, between 6 and 18 months later, all the children were well with normal biochemical and haematological findings.

The rate of recovery from the illness (Table 4), as judged by the number of days for the platelet count to become normal $\left(\geqslant 150 \times 10^{9} / 1\right)$ and the duration of dialysis required, was very similar in all dialysed patients whether they had been heparinised or not. All patients needed transfusions of similar amounts of blood. No complications of heparin treatment were encountered, but its use in thrombocytopenic patients is hazardous. In an outbreak of HUS in 1970 we saw a heparinised child succumb with a massive pulmonary haemorrhage. If heparin has a role in halting the underlying intravascular coagulation believed to occur in HUS, it would be expected to accelerate the rate of rise in platelets, but no such effect was seen. This supports the views of others ${ }^{3-4}$ who feel that there is no indication for heparinising children with this condition.

Peritoneal dialysis proved to be a quick and efficient method of correcting fluid and electrolyte abnormalities. White cells were noted in the effluent dialysate of 6 patients, and these fluids subsequently grew bacteria (Table 5). Peritoneal infections were successfully treated by adding gentamicin to the dialysis fluid in all patients except Cases 2 and 4. Case 2 had slight clinical peritonitis and had already begun to produce urine; therefore the catheter was removed allowing rapid recovery with parenteral antibiotics alone. Cultures from Case 4 showed a haemolytic streptococcus and he was treated with parenteral benzylpenicillin with good results. No other patient had any sign or symptom of peritonitis although 3 were slightly febrile. Case 9 developed pulmonary oedema which was soon corrected by dialysing with hyperosmolar fluid.

There were no permanent sequaelae after

Table 5 Complications of peritoneal dialysis

\begin{tabular}{llll}
\hline Case & Bacterial culture & Clinical signs & Treatment \\
\hline 2 & Escherichia coli & Peritonitis & Gentamicin and removal of catheter \\
3 & Pseudomonas & - & Gentamicin \\
4 & Haemolytic streptococci & - & Gentamicin and benzylpenicillin \\
5 & - & - & - \\
6 & Staphylococcus aureus & Febrile & Gentamicin \\
7 & Staphylococcus aureus & Febrile & Gentamicin \\
8 & Staphylococcus aureus & Slight pulmonary oedema but & Gentamicin and dialysis with \\
9 & & afebrile & hyperosmolar dialysis fluid \\
\hline
\end{tabular}


peritoneal dialysis. Haemodialysis is recommended as the method of choice for treatment of severe HUS ${ }^{11}$, despite the complications associated with vascular shunts in children. In a study on 7 children (6 of whom survived) complications included a case of median and ulnar nerve paresis, and the need to amputate a finger. Dialysis by the peritoneal route is cheaper and simpler to perform, and requires considerably less expertise to initiate than does the insertion of a suitable vascular shunt in a small ill child. We feel that we have further demonstrated the effectiveness of peritoneal dialysis ${ }^{3-4}$ in this condition.

Case 3, who at 7 days had the longest period of predialysis oliguria, and Case 9 , who at 4 days had the greatest duration of certain anuria, both took slightly longer than the other children to achieve normal platelet counts ( 9 and 10 days compared with a mean of 6.5 ) and needed longer periods of dialysis (14 and 13 days compared with a mean of 6.5 for the other 6 patients). The importance of early dialysis in improving survival in HUS has been stressed, ${ }^{12}$ and the necessity to avoid fluid overloading in acute renal failure has been emphasised. ${ }^{13}$

Despite our small sample, the longer time taken for recovery in the 2 children who were diagnosed and treated later then the rest supports still further the policy of early intervention.

No bacterial or viral pathogens were identified from the admission specimens, and no rises in viral antibody titres were recorded. However Case 4 was the only child to have had a stool specimen taken in the early stages of the diarrhoeal illness 3 days before hospital referral and Shigella flexneri was cultured at that time. Repeat cultures after admission did not show this pathogen.

It is probable that HUS has several aetiological factors. ${ }^{14}$ The fact that small outbreaks occur suggests that infective agents are sometimes responsible, and several types of pathogens have been associated with the condition. Shigella has sometimes been associated with outbreaks and in a prospective study of shigellosis in Bangladesh, children who developed HUS had evidence of circulating endotoxins..$^{15}$ It is possible that in our patients the same mechanism triggered the onset of the syndrome and that by the time of admission the original pathogen had been eliminated.

Recurrent cases of HUS have been recorded, and these have tended to be fairly mild. ${ }^{4}$ It has also been recognised that the illness can occur at different times to more than one member of a family. ${ }^{16}$ We recently saw two brothers develop the syndrome together. These data suggest that there may be factors peculiar to the children which render them susceptible to developing the illness. Further support for this view
Table $6 H L A$ typing. HLA antigen frequency compared with that expected normally

\begin{tabular}{llcllc}
\hline HLA & Cases & Expected & HLA & Cases & Expected \\
\hline A1 & 2 & 2 & B7 & 2 & 2 \\
A2 & 5 & 4 & B8 & Nil & 2 \\
A3 & 2 & 2 & B12 & 3 & 2 \\
Aw24 & 2 & 1 & B14 & 2 & $<1$ \\
Aw19 & 1 & $<1$ & B15 & 1 & 1 \\
A32 & 1 & $<1$ & Bw49 & 1 & $<1$ \\
& & & B40 & 1 & 1 \\
& & & B27 & 1 & $<1$ \\
& & & B18 & 1 & $<1$ \\
& & & B13 & 1 & $<1$ \\
\hline
\end{tabular}

is seen in Case 4 whose 4-month-old brother shared her prodromal diarrhoeal illness but did not go on to develop HUS. We performed HLA typing on most of our patients in order to see whether a genetic predisposition to develop the syndrome might be expressed by unusual HLA type distributions. However, the distribution was no different from that predicted to occur by chance (Table 6).

I thank Dr R H Jackson for his help, and the other consultant paediatricians at the Royal Victoria Infirmary, Newcastle, for allowing me to study their patients.

\section{References}

1 Gasser V C, Gautier E, Steck A, Siebenmann R E, Oechslin R. Hämolytisch-urämiche Syndrome: Bilaterale Nierenrindennekrosen bei akuten erworbenen hämolytischen Anämien. Schweiz Med Wochenschr 1955; 85: 905-9.

2 Shinton N K, Galpine J F, Kendall A C, Parry Williams H. Haemolytic anaemia with acute renal disease. Arch Dis Child 1964; 39: 455-64.

3 Tune B M, Leavitt T J, Gribble T J. The hemolyticuremic syndrome in California. A review of 28 nonheparinized cases with long-term follow-up. $J$ Pediatr 1973; 82: 304-10.

4 Kaplan B S, Thompson P D, de Chadarevian J P. The hemolytic-uremic syndrome. Pediatr Clin North Am 1976; 23: 761-78.

5 Gilchrist G S, Lieberman E, Ekert H, Fine R N, Grushkin C. Heparin therapy in the haemolytic-uraemic syndrome. Lancet 1969 ; i : 1123-6.

- Moncrieff M W, Glasgow E F. Haemolytic-uraemic syndrome treated with heparin. $B r$ Med J 1970; iii : 188-91.

7 Vitacco M, Avalos J S, Gianantonio C A. Heparin therapy in the hemolytic-uremic syndrome.J Pediatr 1973; 83: 271-5.

8 Powell H R, Ekert H. Streptokinase and anti-thrombotic therapy in the hemolytic-uremic syndrome. $J$ Pediatr $1974 ; 84: 345-9$.

- Arenson E B, Jr, August C S. Treatment of the hemolyticuremic syndrome with aspirin and dipyridamole. $J$ Pediatr 1975; 86: 957-61.

10 Stuart J, Winterborn M H, White R H R, Flinn R M. Thrombolytic therapy in haemolytic-uraemic syndrome. Br Med J 1974; iii: 217-21. 
11 Ekberg M, Holinberg L, Denneberg T. Haemolyticuraemic syndrome; results of treatment with haemodialysis. Acta Paediatr Scand 1977; 66: 693-8.

12 Kaplan B S, Katz J, Krawitz S, Lurie A. An analysis of the results of therapy in 67 cases of the hemolytic-uremic syndrome. J Pediatr 1971 ; 78 : 420-5.

13 Counahan R, Cameron J S, Ogg C S, et al. Presentation, management, complications, and outcome of acute renal failure in childhood: five years' experience. $\mathrm{Br} \mathrm{Med} \mathrm{J}$ 1977 ; i: 599-602.

14 Kaplan B S, Drummond K N. The hemolytic-uremic syndrome is a syndrome. $N$ Engl J Med 1978; 298: 964-6.
15 Koster F, Levin J, Walker L, et al. Hemolytic-uremic syndrome after shigellosis. $N$ Engl J Med 1978; 298: 927-33.

16 Edelsten A D, Tuck S. Familial haemolytic-uraemic syndrome. Arch Dis Child 1978; 53: 255-6.

Correspondence to Dr M G Coulthard, Department of Paediatrics, The Royal Victoria Infirmary, Queen Victoria Road, Newcastle upon Tyne NE1 4LP.

Received 12 June 1979

The following articles will appear in future issues of this journal:

Lactoferrin in human milk: its role in iron absorption and protection against enteric infection in the newborn infant. $J \boldsymbol{H}$ Brock

One year's study of growth and total hydroxyproline excretion in scoliotic children. $S$ Clark, A Harrison, and $P$ A Zorab

Improving prognosis for infants weighing $1000 \mathrm{~g}$ or less at birth. $V Y H Y u$ and E Hollingsworth

Growth in height compared with advancement in skeletal maturity in patients treated with human growth hormone. R D G Milner, $M A$ Preece, and J M Tanner

$\alpha$-Thalassaemia and hyperbilirubinaemia in G-6-PD-deficient newborns. T Meloni, $R$ Corti, S Costa, G Mele, and V Franca

Hydroxyprolinaemia with normal development. MJ Robinson, I S Menzies, and I Sloan 